\title{
The Effect of the Feed Oil and Protein Source on the Deposition and Depletion of Oxolinic Acid in Farmed Atlantic Salmon (Salmo salar L.)
}

\author{
Bjørn Tore Lunestad ${ }^{1 \star}$, Merat Behzadzadeh', Ole Samuelsen ${ }^{2}$, \\ Marit Espe ${ }^{1}$ and Marc H.G. Berntssen ${ }^{1}$
}

${ }^{1}$ National Institute of Nutrition and Seafood Research (NIFES), Bergen, Norway

P.O. Box 2029 Nordnes, 5817 Bergen, Norway

${ }^{2}$ Institute of Marine Research, Fish Disease Group, P.O. Box 1870 Nordnes, 5817 Bergen, Norway

\begin{abstract}
Fish feed has traditionally been based on the marine ingredients fish oil and fish meal. Pressure on feral fish stocks and rapidly growing aquaculture has lead to the need for development of novel aquafeeds that rely less on fish meal and fish oil, with plant ingredients or alternative marine feed components as feed ingredient replacements. The present study investigates the muscle and liver deposition and elimination of the antibacterial agent oxolinic acid (OA) administered per os to post smolt Atlantic salmon (Salmo salar L.) in conventional and a novel substitution fish feed based on vegetable ingredients and krill meal.

Atlantic salmon post smolt (start weight $\sim 350 \mathrm{~g}$ ) was reared for 2.5 months on either a conventional or a maximum substitution diet. Subsequently, the fish were fed on OA supplemented conventional or substitution diets supplemented with $5 \mathrm{OA} \mathrm{g} / \mathrm{kg}$, with a target dose rate of $\mathrm{OA}$ of $15 \mathrm{mg} / \mathrm{kg}$ fish/day for 5 days, followed by a 28 day depuration period on OA free conventional or substitution feed. Fish in either group were held in three individual tanks, and at each sampling point three fish form each tank were sampled and analysed, giving a total number of nine parallels. The concentration of OA in muscle and liver were examined by an LC-MS (API-ES) method with a lower limit of detection (LOD) of $5.0 \mathrm{ng} / \mathrm{g}$ and a lower limit of quantification (LOQ) of $10.0 \mathrm{ng} / \mathrm{g}$.
\end{abstract}

To assess the relative muscle and liver deposition of OA among fish fed the two diets, the area under the curve (AUC) ratios in muscle and liver for replacement feed (r) and conventional feed (c) was calculated as $\mathrm{AUC}_{\mathrm{s}} / \mathrm{AUC}_{\mathrm{c}}$ $\mathrm{x} 100 \%$. This ratio in muscle was $73.4 \pm 2.2 \%$, whereas for liver samples it was $85.1 \pm 4.0 \%$, indicating a lower OA deposition for substitution feed compared to conventional feed. The lower deposition is explained by a lower feeding rate for the fish fed on substitution diets compared mg OA g fish ${ }^{-1} \mathrm{day}^{-1}$ respectively), due to a lower voluntary feed intake. A minor though significant difference in elimination was observed between the two diets with halfventional and substitution feed, respectively.

Keywords: Oxolinic acid; Feed composition; Pharmacokinetics; Vegetable ingredients to the conservative diets $(0.024 \pm 0.0029$ and $0.034 \pm 0.0027$ lives $\left(\mathrm{t}_{1 / 2} \beta \mathrm{h}\right.$ ) of $189.6 \pm 4.3$ and $211.2 \pm 8.4$ hours for con-

\section{Introduction}

Aquaculture food products are a major and growing source of food for humans. A continuous growth in production of culture species is highly dependent on a stable and sustainable supply of feed ingredients. Fish feed has traditionally been based on marine fish oil and fish meal. In addition, about $15 \%$ of the diet has previously been wheat or other starch-rich ingredients. Due to limitations in available marine resources, it is currently a need to find replacements for fish meal and fish oil, without simultaneously affecting the growth performance, the health and welfare of the fish, or consumer acceptability and health benefits from fish consumption. In this respect vegetable meal and vegetable oils are strong candidates to their marine counterparts (Torstensen et al., 2008). A recent development is thus the partial replacement of conventional marine feed ingredients with suitable vegetable ingredients or marine ingredients, such as krill meal (Torstensen et al., 2008). Whereas most research focuses on aquacultural performance and nutritional aspects of the novel replacement feeds, little emphasis has been put on the efficacy of feed supplements, such as veterinary drugs, when using these new feeds. The diet composition has previously been shown to influence the muscle deposition and elimination of dietary veterinary drugs in farmed fish (Luzzana et al., 1994).

Oxolinc acid (OA) is a synthetic antibacterial agent found in the quinolone class (Wolfson et al., 1989). This agent is bactericidal and has a broad-spectrum activity, making it an attractive candidate as a therapeutic against bacterial diseases in fish (Treves-Brown, 2000). Since its introduction in 1987, OA has found broad use in Norwegian aquaculture and has to a large extent replaced drugs like oxytetracycline (Lunestad and Grave, 2005). OA inhibits bacterial growth by interfering with the enzyme DNA-gyrase, which is essential in the coiling and de-coiling of bacterial DNA during replication (Wolfson et al., 1989). Due to the low Minimum inhibitory concentration (MIC) value

\footnotetext{
*Corresponding author: Bjørn Tore Lunestad, National Institute of Nutrition and Seafood Research (NIFES), Bergen, Norway, P.O. Box 2029 Nordnes, 5817 Bergen, Tel: + 4797596 245; E-mail: $\underline{\text { blu@nifes.no }}$

Received December 26, 2009; Accepted January 19, 2010; Published January 19, 2010

Citation: Lunestad BT, Behzadzadeh M, Samuelsen O, Espe M, Berntssen MHG (2010) The Effect of the Feed Oil and Protein Source on the Deposition and Depletion of Oxolinic Acid in Farmed Atlantic Salmon (Salmo salar L.). J Bioequiv Availab 2: 006-010. doi:10.4172/ jbb.1000022

Copyright: ( $) 2010$ Lunestad BT, et al. This is an open-access article distributed under the terms of the Creative Commons Attribution License, which permits unrestricted use, distribution, and reproduction in any medium, provided the original author and source are credited.
}

J Bioequiv Availab

Volume 2(1): 006-010 (2010) - 006 
Citation: Lunestad BT, Behzadzadeh M, Samuelsen O, Espe M, Berntssen MHG (2010) The Effect of the Feed Oil and Protein Source on the Deposition and Depletion of Oxolinic Acid in Farmed Atlantic Salmon (Salmo salar L.). J Bioequiv Availab 2: 006-010. doi: $10.4172 / \mathrm{jbb} .1000022$

for most susceptible fish pathogens and effective systemic distribution when administered orally, OA have been used extensively to treat systemic bacterial infections in fish (Austin et al., 1983; Rodgers and Austin, 1983; Martinsen, 1993; Rodgers, 2001; Samuelsen and Bergh, 2004; Samuelsen, 2006a; Samuelsen, 2006b).

The amount of antibacterial agents used in Norwegian aquaculture in 2008 was only some few percent of the amount applied in treatments of fish in 1987, even though the production of fish has increased steadily. The reason for this substantial reduction in drug consumption, are the introduction of effective vaccines, selection of more optimal farm sites and a general improvement of farm hygiene. The main proportion of antimicrobial agents is currently applied for newer species in Norwegian aquaculture, mainly Atlantic cod (Gadus morhua) (Grave et al., 2008). In 2008 the following amounts of antibacterial agents were used (kg active substance): oxolinic acid $(681 \mathrm{~kg})$, florfenicol (166 kg) and flumequine $(1 \mathrm{~kg})$, oxytetracycline $(23 \mathrm{~kg})$ and lincomycine/spectinomycine $(70 \mathrm{~kg})$. These agents were administered orally as medicated fish feed pellets. Updated statistics are available at http://www.fhi.no/eway/ default.aspx?pid=233\&trg=Area_5774\&MainArea_5661= 5565:0:15,2675:1:0:0:::0:0\&MainLeft_5565=5774: 0:15,2675:1:0:0:::0:0\&Area_5774=5544:73845::1:5776:1:::0:0 (Tables in Norwegian). As the most extensively used antibacterial agent for fish, OA were chosen in the present experiment.

The present study investigates differences in the deposition and elimination of the quinolone antibacterial agent oxolinic acid (OA) administered to post smolt Atlantic salmon (Salmo salar L.) per os via conventional or novel substituted fish feed based on vegetable oil and protein and an alternative krill protein. The aquacultural performance and nutritional composition of Atlantic salmon fed the conventional and novel feeds have been described elsewhere (Torstensen et al., 2008).

\section{Material and Methods}

\section{Feed production}

For the present trial a conservative marine ingredient diet and a plant and krill based substitution dry pellet diet was produced by Skretting ARC, Stavanger, Norway. Extruded feed with a pellet size of $4 \mathrm{~mm}$ was produced. The overall general composition of the bulk raw materials was $62 \%$ fish meal, $9 \%$ plant meal, and $29 \%$ fish oil for the conventional diet, and $12 \%$ fish meal, $53 \%$ plant meal, $5 \%$ krill meal, $21 \%$ plant oils, and $9 \%$ fish oil for the substitution diets (Table 1). For the medicated feed, oxolinic acid (OA) (Norsk Medisinaldepot AS, Oslo) were mixed into the oils fraction and sprayed onto the conventional and substitution feed to a final concentration of $5.0 \mathrm{~g} / \mathrm{kg}$ feed.

\section{Fish and study site}

The feeding trial was carried out at Matre Aquaculture Research Station, Matredal, Norway during June and November 2006. Post smolt Atlantic salmon with a start weight of $\sim 350 \mathrm{~g}$ were reared on either conventional or substitution diet for 2.5 months until weight had doubled (final average \pm SD weight $(\mathrm{g})$ $786 \pm 111$ and $716 \pm 127$ for conventional and substitution diets, respectively. Torstensen et al. (2008), gives further details on the trial. For the medication trial, a total of 120 of either conven-

\begin{tabular}{|l|c|c|}
\hline Diet & Conventional feed & Substituted feed \\
\hline Wheat & 127 & 111 \\
\hline Wheat gluten & - & 150 \\
\hline Corn gluten & - & 150 \\
\hline Soybean meal extracted & - & 130 \\
\hline Krill meal & - & 50 \\
\hline Fish meal & 620 & 120 \\
\hline Linseed oil & - & 30 \\
\hline Palm oil & - & 60 \\
\hline Rapeseed oil & - & 110 \\
\hline Fish oil & 250 & 70 \\
\hline L-Lysine & - & 13 \\
\hline Histidine-HCl & - & 1 \\
\hline DL-Methionine & - & 1 \\
\hline Vitamins and minerals & 3 & 4 \\
\hline
\end{tabular}

Table 1: Dietary composition $(\mathrm{g} / \mathrm{kg})$ of the conventional and substituted feed applied in the present trial. In addition tho the components lisetd in the table, the feed were supplied with oxolinic acid in a final concentration $5.0 \mathrm{~g} / \mathrm{kg}$ feed. This agent were mixed into the oil fraction and sprayed onto both the conventional and substitution feed. Vitamins and minerals were added to fulfil the requirement for Atlantic salmon.

tional or substitution diet reared salmon were stocked randomly in triplicate indoor fibreglass tanks each of 1000 litres and with a continuous flow through of seawater of $501 / \mathrm{min}$. Average water temperature and salinity throughout the experimental period was $12.6^{\circ} \mathrm{C}($ S.D. $=0.5)$ and $28.6^{\circ} \mathrm{C}($ S.D. $=0.85)$ respectively. After acclimatisation periods of 14 days on the two different diets, fish from each dietary group were fed OA enriched conventional and substitution diets.

\section{Medication and sampling}

The fish were fed for 5 consecutive days on OA supplemented diets $(5 \mathrm{~g} / \mathrm{kg}$ feed), with a dose rate of $15 \mathrm{mg} \mathrm{OA} / \mathrm{kg}$ fish/day. The medication period was followed by a sampling period of 33 days, where the fish were fed on either conventional or substitution diets without $\mathrm{OA}$.

Before sampling, the fish were anesthetised by benzocaine (Bezoak vet. A.C.D.) in a concentration of $40 \mathrm{mg}$ / litre sea water and sacrificed by a blow on the head. Samples of muscle without skin and liver were placed in separate plastic vials. When collecting liver samples, special care was made not to puncture the gall bladder. All samples were transported on ice reaching the laboratory within four hours, and immediately frozen at $20^{\circ} \mathrm{C}$.

\section{Sample preparation, extraction and clean up}

Liver or muscle samples of $2.0 \mathrm{~g}$ were homogenised and transferred to a $25 \mathrm{ml}$ centrifuge tube. OA were extracted from the tissue using $10 \mathrm{ml}$ ultrapure water. After mixing and ultrasound treatment for 5 minutes, the sample was centrifuged. ( $5 \mathrm{~min}, 3000$ rpm, Eppendorf 5810 R). Purification was performed in an ASPEC purification robot (XL4 Gilson, 735 sampler software). The clean-up was carried out using a $\mathrm{C}_{18}$ SPE cartridge (Bond Elute, Varian). The columns were conditioned with $6 \mathrm{ml}$ methanol and $5 \mathrm{ml}$ ultrapure water. After application of the extract, the cartridge was rinsed with $2 \mathrm{ml}$ methanol: water (20:80), $2 \mathrm{ml}$ heptane and dried by nitrogen for 8 minutes before elution with $3 \mathrm{ml} \mathrm{1 \%}$ formic acid in acetonitrile. The eluates were evaporated to dryness at $45^{\circ} \mathrm{C}$ under a stream of nitrogen. The residues was dissolved in $40 \mu \mathrm{L}$ methanol and $160 \mu \mathrm{L} 0.1 \%$ formic 


\section{Journal of Bioequivalence \& Bioavailability - Open Access}

JBB/Vol.2 Issue 1

acid. The solution was filtered through a $0.45 \mu \mathrm{m}$ syringe filter (Millipore) before injecting $20 \mu \mathrm{L}$ on the HPLC column. All regents were of HPLC grade and water was purified in a Milli-Q system. Flumequine was added as an internal standard prior to homogenisation of the samples.

\section{Instrumentation}

The concentration of OA in muscle and liver were examined by an LC-MS method. The LC equipment was a Hewlett Packard1100 series quaternary pump supplied with a $3.0 \times 150$ $\mathrm{mm}, 5 \mu \mathrm{m}$, Symmetry column from Waters. The mobile phase consisted of $0.1 \%$ formic acid in water (A) and $0.1 \%$ formic acid in methanol (B), starting at $20 \%$ B from 0 to 5 minutes, and increasing to $100 \% \mathrm{~B}$ at $26 \mathrm{~min}$ following a linear gradient. The flow rate was $0.4 \mathrm{ml} / \mathrm{min}$. Mass spectrometric detection was carried out with a Hewlett Packard MSD quadrupole instrument with electrospray ionisation (ESI) interface in positive ion-mode. The conditions included a Selected Ion Monitoring (SIM) of 262.9, a gas flow of $10.0 \mathrm{ml} / \mathrm{min}$, nebulizer pressure of $40 \mathrm{psig}$, a gas temperature of $300^{\circ} \mathrm{C}$ and a capillary voltage of $3500 \mathrm{~V}$. The concentration of OA was calculated by a three point calibration.

\section{Feeding rates}

Mean feeding rates $(F R)$ were calculated as the amount of feed in $\mathrm{mg}$ ingested per $\mathrm{g}$ fish on a daily basis ( $\mathrm{mg}$ feed/g fish/d).

\section{AUC and half-lifes}

The area under the curve (AUC) was calculated manually from the graphs using the trepezoid rule and including the results from sampling at day 28 after the initiation of medication. The depletion of OA from tissues of medicated fish was described by determining the best-fit exponential model for each tissue by means of least square method. Estimates of the best-fit exponential model were for the one-exponential equation $\mathrm{C}=\mathrm{Ae}^{-\beta \mathrm{t}}$, with $\beta$ as the first phase elimination rate. Respective half-lives from the elimination rate constant were calculated as $\mathrm{t}_{1 / 2} \beta=0.693 \beta^{-1}$.

\section{Results}

The concentration of $\mathrm{OA}$ in muscle and liver after per oral medication by conventional and a vegetable-krill substituted diets are shown in Figure 1. The conservative diet group had higher concentrations of OA in both muscle and liver. The highest OA concentrations observed were measured two days after the termination of medication and found to be 46.3 and $13.6 \mathrm{mg} / \mathrm{kg}$ in liver and muscle respectively, in fish feed the conservative diet. Corresponding values in fish fed the substituted diet were 38.2 and $9.7 \mathrm{mg} / \mathrm{kg}$ respectively. In Table 2 the calculated feeding rates ( $\mathrm{mg}$ feed $\mathrm{g}$ fish $^{-1}$ day $\left.^{-1}\right)$ and half-lives in hours $\left(t_{1 / 2} \beta(\mathrm{h})\right)$ in the elimination phase for OA in muscle are shown.

The Area under the curve (AUC day 2 - 24) ratios for OA in muscle and liver for substituted feed (s) and conventional feed (c) was calculated as $\mathrm{AUC}_{\mathrm{s}} / \mathrm{AUC}_{\mathrm{c}} \mathrm{x} 100 \%$. The calculations were done for each of the individual tanks included in the experiment. The ratio was found to be $73.4 \pm 2.2 \%$ in muscle and $85 \pm 4.0 \%$ in liver. The percentage deviation represents the differences among tanks. Despite the acclimatisation period the feeding rate was lower for the fish fed on substitution diet than the conservative diet $(4.84 \pm 0.57$ and $6.78 \pm 0.53 \mathrm{mg}$ feed $\mathrm{g}$ fish ${ }^{1}$ day $^{-1}$ respectively). The feeding rate $(F R)$ of the fish given sub-

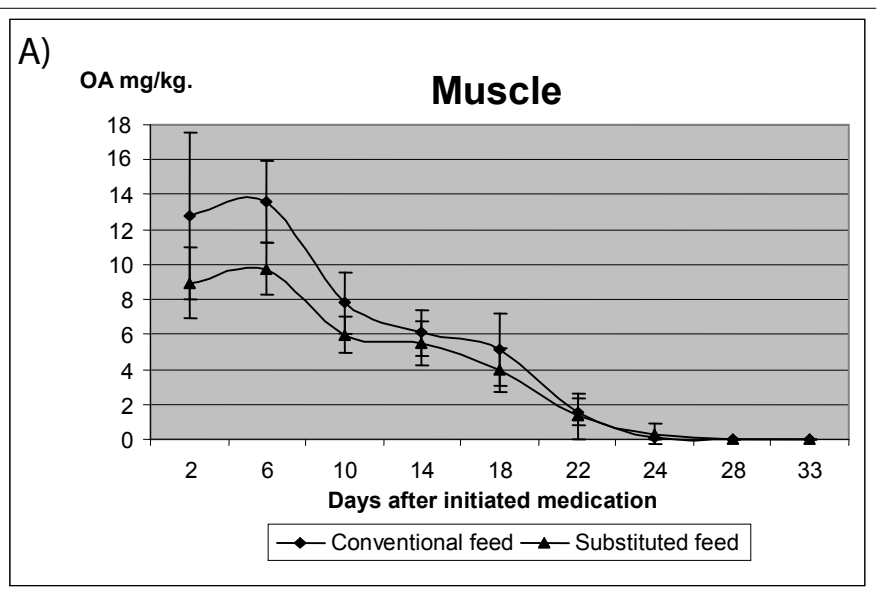

B)

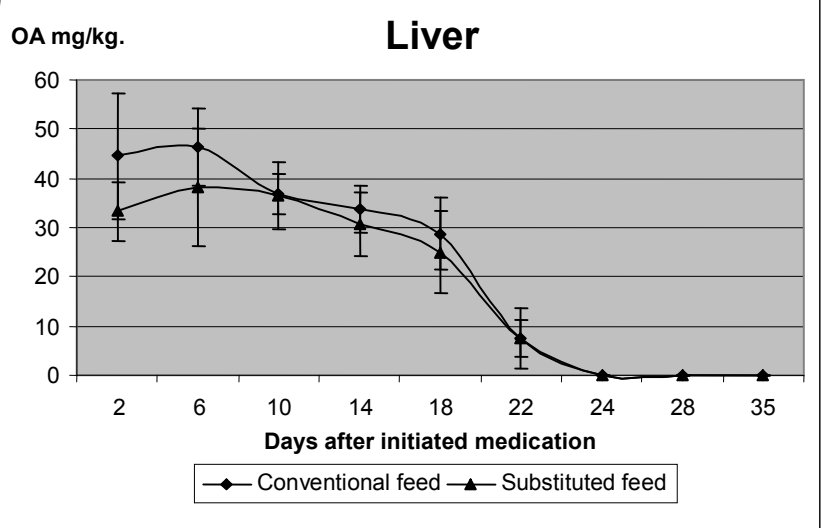

Figure 1: Concentration versus time curves for Oxolinic acid (OA) in muscle (a) and liver (b) of salmon (Salmo salar L.) following a five days per os treatment by conventional feed or a vegetable/krill substituted diet added OA in a concentration of $5 \mathrm{~g} \mathrm{~kg}^{-1}$ feed. The dose rates of OA were $15 \mathrm{mg} / \mathrm{kg}$ fish/day. Each data point represents nine individual fish.

\begin{tabular}{|c|c|c|}
\hline & Conventional feed $\left(_{c}\right)$ & Substituted feed $\left(_{\mathrm{s}}\right)$ \\
\hline Feeding rate $(F R)$ & $6.78 \pm 0.53$ & $4.84 \pm 0.57$ \\
\hline $\mathrm{t}_{1 / 2} \beta(\mathrm{h})$ & $189.6 \pm 4.3$ & $211.2 \pm 8.4$ \\
\hline $\mathrm{AUC}_{\mathrm{s}} / \mathrm{AUC}_{\mathrm{c}} \times 100 \%$ & 100 & $73.4 \pm 2.2$ \\
\hline
\end{tabular}

Table 2: Feeding rates $(F R)\left(\mathrm{mg}\right.$ feed $\left.\mathrm{g} \mathrm{fish}^{-1} \mathrm{day}^{-1}\right)$, half-life $\left(\mathrm{t}_{1 / 2} \beta\right)$ in hours, and \% AUC ratio (AUC $/$ AUC $_{c} \times 100 \%$ ) in muscle for OA when feed to post smolt Atlantic salmon (Salmo salar L.) in a conservative marine ingredient based diet or a plant-krill substitution diet. The feed OA concentration was $5 \mathrm{~g}$ $\mathrm{kg}^{-1}$, and the applied dose rate were $15 \mathrm{mg} / \mathrm{kg}$ fish/day for 5 days.

stituted feed was $71.4 \%$ of that found for the group feed the conventional diet. The elimination of $\mathrm{OA}$ from both muscle and liver was best described by a one-exponential equation. Terminal half life in hours for muscle in fish fed conventional feed or substitution feed were 189.6 $\pm 4.3 \mathrm{D}$ and $211.2 \pm 8.4 \mathrm{D}$, respectively, with significant differences among the two dietary groups $(\mathrm{p}<0.05, t$-test).

\section{Discussion}

Despite an acclimatisation period of two weeks, the feeding rate $(F R)$ was lower for the fish fed on substitution diet than the conservative diet, indicating a reduced appetite in the fish fed the substitution diet. The fish given substituted diets had an FR of $71.4 \%$ of what was found for the group fed the conventional diet. Reduced feed intake in fish fed the substituted feed was also found in a 12 month trial with post-smolt Atlantic salmon fed diets in which high replacement of both protein and lipid was tested (Torstensen et al., 2008). It has also been documented 
Citation: Lunestad BT, Behzadzadeh M, Samuelsen O, Espe M, Berntssen MHG (2010) The Effect of the Feed Oil and Protein Source on the Deposition and Depletion of Oxolinic Acid in Farmed Atlantic Salmon (Salmo salar L.). J Bioequiv Availab 2: 006-010. doi:10.4172/jbb. 1000022

that OA itself may influence on the appetite (Hustvedt et al., 1991; Rigos et al., 1999). However in the present trial, equal OA concentrations were added in both feeds, and should thus not give drug dependant differences in the appetite of the experimental fish. The reduced voluntary feed intake in the fish fed the substituted diet could probably be explained by the high inclusion of plant ingredients. This also was found in a trial with European seabass (Dicentrarchus labrax) (Dias et al., 2005) and Atlantic salmon (Espe et al., 2006). Thus total replacement seems to interact with metabolism and utilisation of the feed.

The maximum OA concentration was obtained two days after the termination of medication for both feeds. The Maximum concentration of OA in liver and muscle of fish feed the conservative diet were 46.3 and $13.6 \mathrm{mg} / \mathrm{kg}$ respectively. The corresponding OA concentrations in liver and muscle of fish feed the substituted diet were 38.2 and $9.7 \mathrm{mg} / \mathrm{kg}$. At day two the OA concentration in the liver of fish medicated via substituted feed were $82.5 \%$ of what was found in the conservative diet group. In samples of muscle in the substituted feed group at day two, the OA concentration was $71.3 \%$ compared to the corresponding concentration in the conservative feed group.

In the study by Steffenak et al. (1991), OA were given for ten days in dose of $25 \mathrm{mg} / \mathrm{kg}$ fish to Atlantic salmon held in seawater with a temperature ranging from 6 to $14^{\circ} \mathrm{C}$. Different tissues of the fish were examined 20,60 and 180 days after end of medication. The highest average OA concentration was found in the backbone showing $1201 \mathrm{ng} / \mathrm{g}$ at day 20 post medication. At the same sampling time the concentration in muscle and liver were 16 and $35 \mathrm{ng} / \mathrm{g}$ respectively. At day 60 post medication, the concentration in muscle and liver were 15 and $47 \mathrm{ng} / \mathrm{g}$, respectively. Even at day 180 post medication, OA could be detected in liver (8 ng/g), fat (2 ng/g), skin (35 ng/g) and bone (478 ng/g).

Ellingsen et al. (2002) studied the pharmacokinetics of OA in Atlantic salmon held in seawater and medicated every other day for seven days by floating feed (Apoxolon Akvaletter) containing the active agent in a concentration of $5 \mathrm{~g} / \mathrm{kg}$. In their study the fish weight was $2 \mathrm{~kg}$ and the rearing water temperature was between 9.5 and $10.5^{\circ} \mathrm{C}$. The authors report maximum liver and muscle concentrations of 5 and $3 \mathrm{mg} / \mathrm{kg}$, respectively. The total given dose of OA in the study of Ellingsen et al. (2002) was 118 $\mathrm{mg}$ per $\mathrm{kg}$ fish, applied as one hand fed intensive dose. The authors do not give information on the proportion of medicated feed that were actually ingested by the fish. In our study the total ingested OA dose was $170 \mathrm{mg}$ per $\mathrm{kg}$ fish in the conventional fed group, and $121 \mathrm{mg}$ per $\mathrm{kg}$ fish in the substituted group. The higher total dose of ingested OA in our study, combined with smaller fish and higher water temperature, may explain the higher concentrations found in both liver and muscle.

The depletion of OA in the present study was best described as one-phase elimination. Most reports on elimination of OA in Atlantic salmon are from single dose trials. In the work by Samuelsen et al. (2000), the reported elimination half-life $\left(\mathrm{t}_{1 / 2}\right)$ for OA in Atlantic salmon of 400 to 500 grams held in seawater at $10^{\circ} \mathrm{C}$, were $20 \mathrm{~h}$ for muscle and $12 \mathrm{~h}$ for liver. The maximum concentrations were however 3.01 and $6.08 \mathrm{mg} / \mathrm{kg}$ for muscle and liver respectively and the drug could not be detected 7 days following administration in any of the tissues. The much longer $\mathrm{t}_{1 / 2}$ values observed in the present study may be a result of the multiple-dose regime causing high maximum concentrations and the long sampling regime uncovering a slower elimination phase not detected by Samuelsen et al. (2000).

According to the reviewed literature, the elimination of OA varies with species, salinity and temperature (Samuelsen, 2006b; Treves-Brown, 2000). In Atlantic cod muscle half-life was $58 \mathrm{~h}$ after receiving a multiple dose of $10 \mathrm{mg} \mathrm{kg}^{-1} \mathrm{BW}$ day $^{-1}$ (Samuelsen, 2006a). In the present study, minor but significant differences in OA half-lives were found between the conventional feed group and the substituted feed group.

In Rainbow trout (Oncorhynchus mykiss) held in fresh water the elimination is 6 times slower than in rainbow trout held in seawater and under otherwise identical experimental conditions. Reported half-lives for OA in fish held in fresh water are 69 and $81 \mathrm{~h}$ respectively for Rainbow trout and Channel catfish (Ictalurus punctatus) (Treves-Brown, 2000).

Since the elimination of xenobiotics are closely linked to transport over membranes, the composition and properties of cell membranes in the experimental fish may be a part of the explanation for the observed differences in elimination half-lives between the two fish groups.

The fatty acid composition of phospholipids (PL) and even more the stored lipids as tri-acyl-glycerol (TAG) is highly dependent on dietary fatty acid composition (Bell et al., 2001; Torstensen et al., 2005; Mørkøre et al., 2007) as well as affected by the rearing temperature (Corraze and Kaushik, 1999).

Interaction between drugs and feed or food matrixes has long been known and are well described. Some authors have focused on the effect of feed ingredients on the absorption of drugs by fish. In a study by Martinsen et al. (1993) the quinolone sarafloxacin was given as a single oral dose in capelin and corn oil. The study showed an enhanced uptake when the drug was suspended in corn oil. However, based on data of feeding rates, it can be concluded that the lower OA concentrations observed in the present study are a consequence of reduced feeding, rather than interactions of the drug with components in the feed.

In conclusion the lower OA concentrations observed in the substitution feed group were mainly a result of reduced appetite. Furthermore, the substitution of marine fish meal and oil by krill meal and vegetable oil seems to have a small, but statistically significant effect on the elimination of OA in Atlantic salmon.

\section{Acknowledgements}

The excellent technical and analytical skills of Lena K. Støten and Per Erik Hagen are highly appreciated. This experiment was performed as part of the EU funded project "AQUAMAX", project number 016249-2.

\section{References}

1. Austin B, Rayment J, Alderman DJ (1983) Control of furunculosis by oxolinic acid. Aquaculture 31: 101-108. »CrossRef » PubMed » Google Scholar

2. Bell JG, McEvoy J, Tocher DR, McGhee F, Campbell PJ, et al. (2001) Replacement of fish oil with rapeseed oil in diets of Atlantic salmon (Salmo salar) affects tissue lipid compositions and hepatocyte fatty acid metabolism. J Nutr 131: 1535-1543. »CrossRef » PubMed » Google Scholar

3. Corraze G, Kaushik S (1999) Lipids from marine and freshwater fish. OCLOleagineux Corps Gras Lipides 6: 111-115. »CrossRef » PubMed » Google Scholar 


\section{Journal of Bioequivalence \& Bioavailability - Open Access JBB/Vol.2 Issue 1}

4. Dias J, Alvarez MJ, Arzel J, Corraze G, Diez A, et al. (2005) Dietary protein source affects lipid metabolism in the European seabass (Dicentrarchus labrax). Comp Biochem Physiol 142: 19-31.»CrossRef » PubMed » Google Scholar

5. Ellingsen OF, Midttun B, Rogstad A, Syvertsen C, Samuelsen OB (2002) Dosage regime experiments with oxolinic acid and flumequine in Atlantic salmon (Salmo salar L) held in seawater. Aquaculture 209: 19-34. » CrossRef » PubMed » Google Scholar

6. Espe M, Lemme A, Petri A, El-Mowafi A (2006) Can Atlantic salmon grow on diets devoid of fish meal? Aquaculture 255: 255-262. » CrossRef » PubMed » Google Scholar

7. Grave K, Hansen KM, Kruse H, Bangen M, Kristoffersen AB (2008) Prescription of antimicrobial drugs in Norwegian aquaculture with an emphasise on "new" fish species. Prev Vet Med 83: 156-169. » CrossRef » PubMed » Google Scholar

8. Hustvedt SO, Storebakken T, Salte R (1991) Does oral administration of oxolinic acid or oxytetracycline affect feed intake of rainbow trout? Aquaculture 92: 109-113. »CrossRef » PubMed » Google Scholar

9. Martinsen B (1993) Quinolones as antimicrobial drugs in aquaculture: Antimicrobial activities and pharmacokinetic properties. Dr. scient Thesis, Norwegian College of Veterinary Medicine, Ås, Norway. » CrossRef » PubMed » Google Scholar

10. Martinsen B, Horsberg TE, Solberg S, Burke M (1993) Single dose kinetic study of sarafloxacin after intravenous and oral administration of different formulations to Atlantic salmon (Salmo salar) held in sea water at $8.5^{\circ} \mathrm{C}$. Aquaculture 118: 37-47. » CrossRef » PubMed » Google Scholar

11. Mørkøre T, Netteberg C, Johnsson L, Pickova J (2007) Impact of dietary oil source on product quality of farmed cod, Gadus morhua. Aquaculture 267: 236-247. » CrossRef » PubMed » Google Scholar

12.Lunestad BT, Grave K (2005) Therapeutic agents in Norwegian aquaculture from 2000 to 2004: Usage and residue control. Bull Eur Ass Fish Pathol 25: 284-290. » CrossRef » PubMed » Google Scholar

13. Luzzana U, Serrini G, Moretti VM, Maggi GL, Valfre F, et al. (1994) Effect of temperature and diet composition on residue depletion of oxytetracycline in cultured channel catfish. Analyst 119: 2757-2759. » CrossRef » PubMed » Google Scholar

14.Poher I, Blanch G (1998) Pharmacokinetics of a discontinuous absorption process of oxolinic acid in turbot, Scophthalmus maximus, after a single oral administration. Xenobiotica 28: 1061-1073. » CrossRef » PubMed » Google Scholar
15. Rigos G, Alexis M, Nengas I (1999) Leaching, palatability and digestibility of oxytetracycline and oxolinic acid in diets fed to seabass (Dicentrarchus labrax L.). Aquaculture Res 30: 841-847. » CrossRef » PubMed » Google Scholar

16. Rodgers CJ, Austin B (1983) Oxolinic acid for control of enteric redmouth disease in rainbow trout. Vet Rec 112: 83. » CrossRef » PubMed » Google Scholar

17. Rogers CJ (2001) Resistance of Yersinia ruckeri to antimicrobial agents in vitro. Aquaculture 196: 325-345. » CrossRef » PubMed » Google Scholar

18. Samuelsen OB, Ervik A, Pursell L, Smith P (2000) Single dose pharmacokinetic study of oxolinic acid and vetoquinol, an oxolinic acid ester, in Atlantic salmon, (Salmo salar), held in sea water and in vitro antibacterial activity against Aeromonas salmonicida. Aquaculture 187:213-224.»CrossRef » PubMed » Google Scholar

19. Samuelsen OB, Bergh $\varnothing$ (2004) Efficacy of Orally Administered Florfenicol and oxolinic acid in the Treatment of Vibriosis in cod (Gadus morhua L.). Aquaculture 235: 27-35. » CrossRef » PubMed » Google Scholar

20. Samuelsen OB (2006a) Multiple dose pharmacokinetic study of oxolinic acid in cod, Gadus morhua L. Aquaculture Int 14: 443-450. » CrossRef » PubMed » Google Scholar

21. Samuelsen OB (2006b) Pharmacokinetics of quinolones in fish: A review. Aquaculture 255:55-75. »CrossRef » PubMed » Google Scholar

22. Steffenak I, Hormazabal V, Yndestad M (1991) Reservoir of quinolone in fish. Food Add Contam 8: 777-780. »CrossRef » PubMed » Google Scholar

23. Torstensen BE, Bell JG, Rosenlund G, Henderson RJ, Graff IE, et al. (2005) Tailoring Atlantic salmon (Salmo salar L.) flesh lipid composition and sensory quality by replacing fish oil with a vegetable oil blend. J Agric Food Chem 53: 10166-10178. » CrossRef » PubMed » Google Scholar

24. Torstensen BEM, Espe M, Sanden M, Stubhaug I, Waagbø R, et al. (2008). Novel production of Atlantic salmon (Salmo salar) protein based on combined replacement of fish meal and fish oil with plant meal and vegetable oil blends. Aquaculture 285: 193-200. » CrossRef » PubMed » Google Scholar

25. Treves-Brown KM (2000) Applied fish pharmacology. Kluwer Academic Publishers, Dordrecht, The Netherlands, ISBN 0-412-62180-0. » CrossRef » PubMed » Google Scholar

26. Wolfson JS, Hooper DC, Swartz MN (1989) Mechanisms of action and resistance to quinolone antimicrobial agents. In: Wolfson JH, Hooper DC (Eds.), Quinolone antibacterial agents. American Society for Microbiology, Washington D.C. » CrossRef » PubMed » Google Scholar 